\title{
Breakdown of hoisting machine in mining shaft hoist installed in southern section of R-II shaft of KGHM Polska Miedź S.A. O/ZG Rudna
}

\begin{abstract}
This article applies to a one-of-its-kind case of the cracking of the main shaft of a hoisting machine that occurred in the southern section of the R-II shaft of KGHM Polska Miedź S.A. Oddziat ZG "Rudna" in 2011. The mining shaft hoists installed in the R-II shaft are not only the basic extraction equipment in the Rudna mine but also throughout KGHM. The unscheduled standstill cases of these hoists generate huge losses for the mine. These reasons resulted in the necessity for the ad hoc repair of the damaged shaft and operational use of the hoist until a new shaft is completed and delivered.

The article describes the works related to the preparation and execution of the repair of the shaft as well as the tests that were performed. The last stage was the preparation of the operational conditions of the shaft of the machine with the repaired shaft with limited kinematic parameters and under strict supervision until the execution of the new shaft.
\end{abstract}

Key words: mining shaft hoist, hoisting machine, main shaft, hoisting machine breakdowns

\section{INTRODUCTION}

The mining shaft hoists installed in the R-II shaft are intended for extracting excavated material in skips with a capacity of $33 \mathrm{Mg}$. After thirty years of intense operational use (since 1974), their comprehensive modernization was ordered. The hoisting machine in the southern section (S) of the R-II shaft was modernized in January of 2004, and the hoisting machine in the northern section $(\mathrm{N})$ of the R-II was modernized in May of 2006. The modernization consisted of replacingthe mechanical part of the machines; that is, the main shaft, hoist drum, bearings, and brake system along with the control elements.

The machine is ready for automatic control and for manual control by the hoisting operator.

The characteristic data of the hoisting machine declared in the documentation is as follows:

- hoist drum diameter

$5500 \mathrm{~mm}$,

- nominal diameter of hoist ropes

50-54 mm,

- number of hoist ropes
- maximum static overweight

- maximum static force

in the four hoist ropes

- shearing force of the four hoist ropes

- maximum speed of excavated material pulling

The hoist drum of the hoisting machine is set on the main shaft supported by two rolling bearings on both sides of the hoist drum. The bearings are lubricated with oil (under pressure) in a closed system. On both of the free ends of the shaft, the rotors of the driving motors are set. The driving system of the hoisting machine consists of two separately excited PW-106 direct current motors with $3600 \mathrm{~kW}$ of power each and powered from DCA 600 series thyristor converters.

The break consists of four break bands with sixteen pairs of actuators (four in each band), and the control and power supply unit are composed of two hydraulic units (one of which is the reserve). The bearings of the main shaft, break bands, stators of the driving 
motors, and equipment for machining the rope grooves are set on the steel hoist tower structure.

This machine in the mechanical part consists of a main shaft set on two rolling bearings, a hoist drum ready for cooperation with four load-bearing hoist ropes, a break acting on two brake discs composed of four bands withfour installed pairs of hydraulically restored brake actuators controlled with a doubleunit control and power supply set, two driving motors, and equipment for machining the rope grooves.

The pulse transmitters connected to the main shaft are used to supervise and control the operation of the machine; i.e.:

- a pulse generator installed on one side of the shaft,

- a tach generator with a pulse generator are set on the other side of the shaft.

The pulse generator driven from the axle of the shaft rope roller pulleys is used to control the travel of the vessels of the shaft hoist.

Both hydraulic units of the control and power supply unit of the break are located at the level of the hoisting machine. Figure 1 presents the view of the machine in the (S) section after modernization.

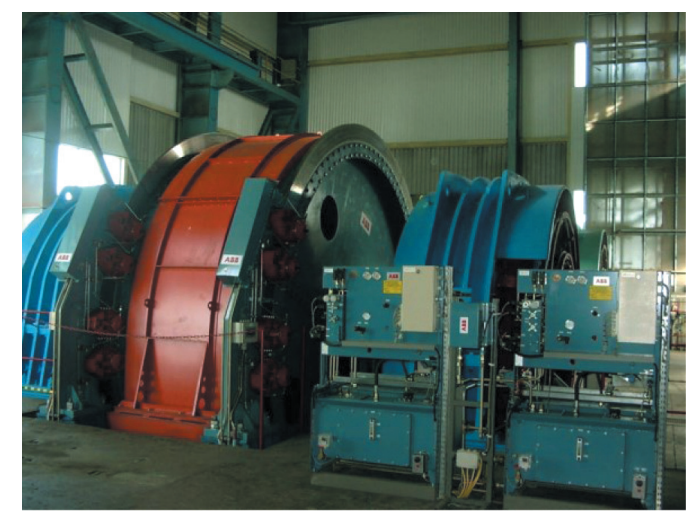

Fig. 1. View ofhoisting machine in section $(S)$ of R-II shaft after modernization in 2004 [1]

On April 17, 2011, the operators of the hoist noticed damage in the shaft of the hoisting machine in the southern section in the area of the passage of the shaft in the flange used to connect with the hoist drum on the eastern side.

A crack as well as chips of the material in some places were visible along about half of the circumference of the shaft. The nature of the damage indicated fatigue crack (Figs. 2 and 3 ).

Due to the possibility of accessing the place of the damage only from the side of the shaft bearing (eastern), an accurate assessment of the damage was possible only after dismantling the hoist drum and completing specialized inspections with visual and magnetic particle methods. These inspections were done on April 17, 2011, by an expert from Autorytet Spółka z o.o. [2]

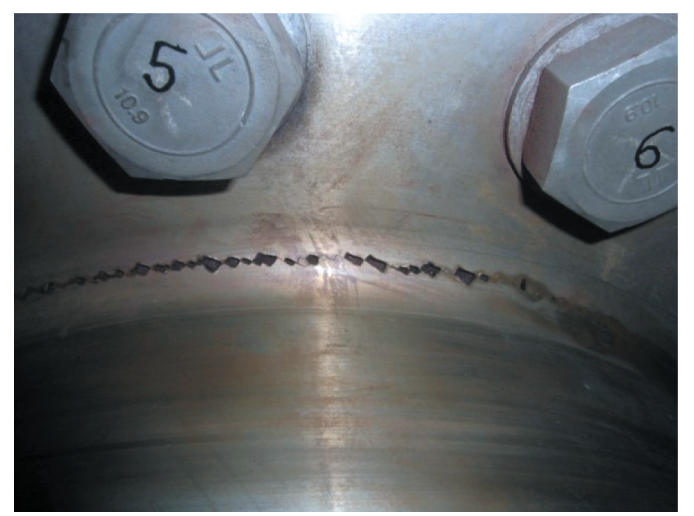

Fig. 2. Cracks in circumference with crushing [1]

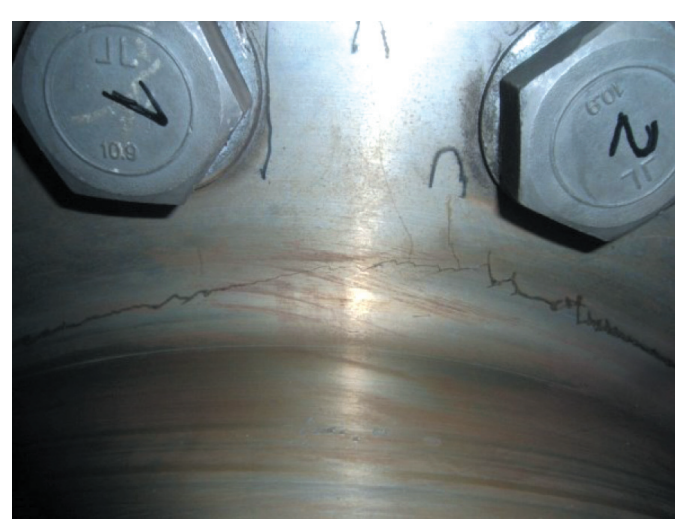

Fig. 3. Cracks oncircumference andradial cracks [1]

On the basis of the inspections, Figure 4 was drawn up with the discovered damages marked.

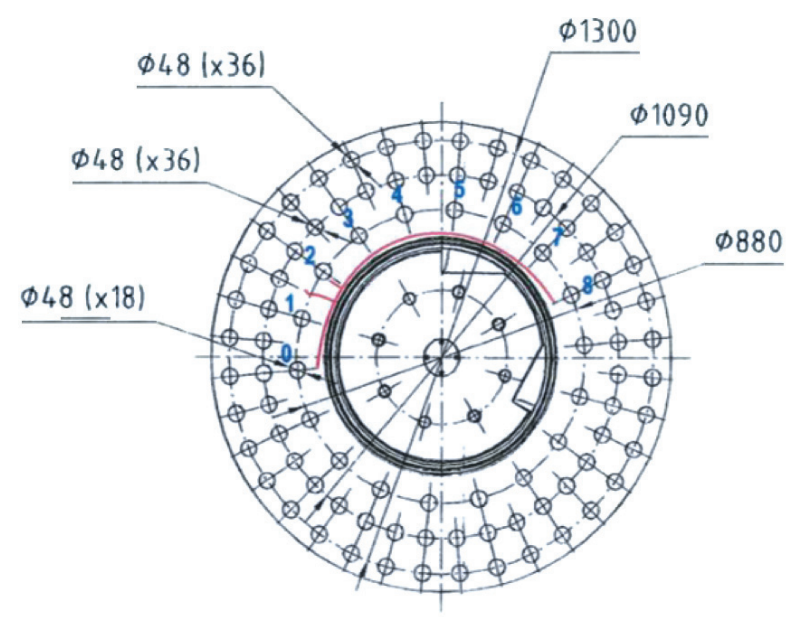

Fig. 4. Side disc of hoist drum of hoisting machine in southern section (eastern side) with cracks marked (red) [2] 
The inspection resulted in the following conclusions:

- a crack on the circumference $\sim 1000 \mathrm{~mm}$ long in the axial direction (in parallel to the axle of the shaft) through the material,

- a crack with some crushing of the material $\sim 460 \mathrm{~mm}$ long in the axial direction through the material,

- two radial cracks (perpendicular to the axle of the shaft) from the circumference $\sim 100 \mathrm{~mm}$ long and $\sim 60 \mathrm{~mm}$ between the Bolts 1 and 2 .

The found damages did not allow for the further operational use of the hoisting machine. The consequence of the above inspections was the decision of the Director of the Mining Office to the Power and Mechanical Equipment Test Inspections to stop the operation of the mining plant in the part related to the mining shaft hoist installed in the southern section of the R-II shaft O/ZG Rudna [3].

\section{CONCEPT OF REPAIR OF SHAFT}

The decision was made to repair the cracked shaft by welding in accordance with the technology developed by the Institute of Welding in Gliwice and agreed with by ZG Rudna [4]. Due to the vast loss of the material of the flange, the preparation of a weld groove was necessary; that is, the execution of the appropriate undercuts (geometry) of the connected elements (Fig. 5). After the appropriate preparation of the edges of the weld groove, penetration tests were conducted (to detect any cracks).

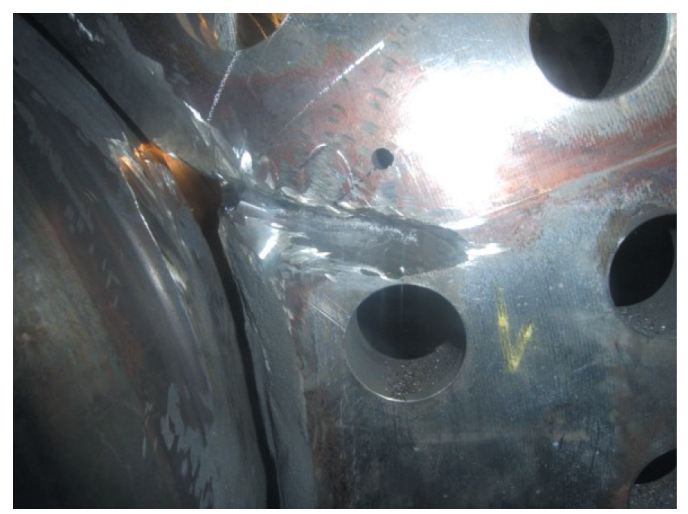

Fig. 5. The repair. Preparation of weld groove with view on depth of flange and size of crack [1]

The area around the site of the repair was isolated and then heated up to a temperature of ca. $100^{\circ} \mathrm{C}$ with an electric heating unit and heating mats ata rate of about $25^{\circ} \mathrm{C} / \mathrm{h}$. After stabilizing the temperature on the shaft and the flange, the welding work was started while at the same time continuously recording the temperature of the elements neighboring the site of the welding (Fig. 6). Special attention was paid to maintaining the difference of the temperatures of the elements of the bearing supporting the shaft within the proper range [5-7].

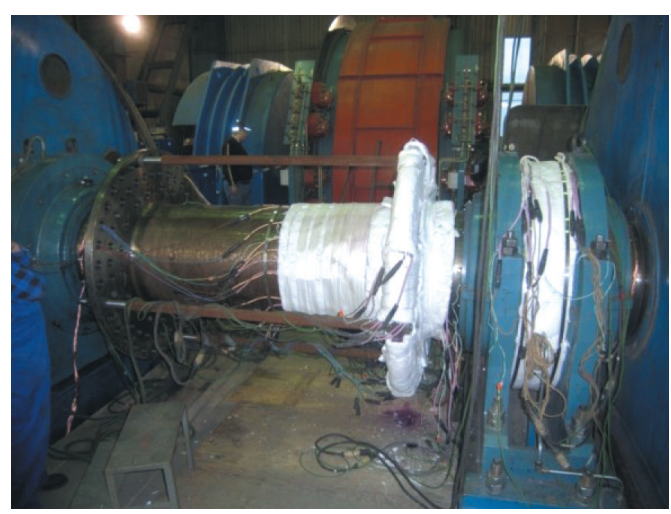

Fig. 6. Area around place of welding was isolated and then heated up with electric heating unit and heating mats. Heating speed was about $25^{\circ} \mathrm{C} / \mathrm{h}$ [1]

To protect the rolling bearing against possible damage as a result of thermal expansion, the bearing case was heated up so that the temperature difference between the internal and external races would not exceed $15^{\circ} \mathrm{C}$.

Due to the fact that the material of the shaft is made of steel with highly difficult weldability (as well as considering the scope of the damage), the welding process was done in two stages. First, the buffer layer was done on the side of the shaft and of the flange. Then, the surface of the buffer layer was properly smoothened by grinding, and the weld groove was started in accordance with the prepared instruction (Fig. 7). Figure 8 presents a view of the part of the shaft in the area of the crack after applying the buffer layer.

The next stage was connecting the flange to the shaft (closing the weld). An ENiCrFe-3 wire was used as a binder according to AWS A 5.11. After connecting the flange with the shaft, the whole weld groove was filled in along with the machining allowance (Fig. 9).

In each stage of the welding work, penetration tests were executed. If cracks were detected, the material was ground to remove them, with the welding work being continued only afterwards. The additional materials used for the welding were selected so as to 
enable the execution of the weld of the difficult-for-welding shaft material and obtain the properties of the weld deposit as close to the properties of the native material of the shaft as possible. The welding work related to the repair of the shaft was executed uninterruptedly (day and night) for about a week.

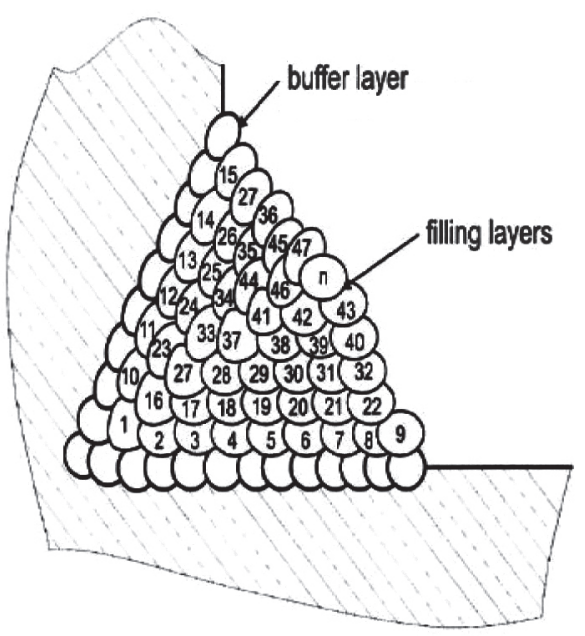

Fig. 7. Order of execution of welding work: buffer layer and filler layer [4]

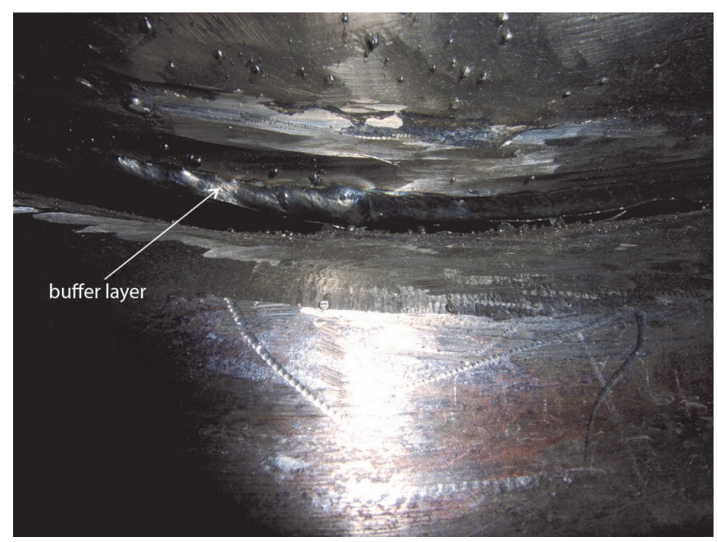

Fig. 8. View of shaft after applying buffer layer [1]

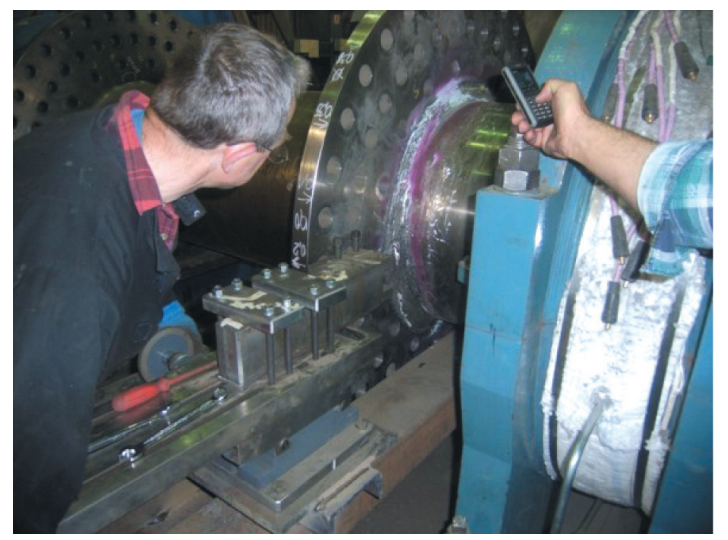

Fig. 9. Machining of shaft after welding to render proper curvature radius for part of shaft [1]

\section{INSPECTION OF MACHINE SHAFT AFTER REPAIR}

After the repair, an inspection of the machine shaft was conducted in order to confirm the readiness of the repaired shaft for further operational use. The inspection was executed by experts from Autorytet Spółka z o.o. $[8,9]$ (a non-destructive inspection of the shaft) and by employees of the Rope Transport Department (Katedra Transportu Linowego) of AGH University of Science and Technology in Krakow (the stress tests), among others. The extensometric tests of the stresses executed by KTL-AGH University of Science and Technology in the cylindrical part of the shaft and in the flange connecting it to the hoist drum as well as the thermovision tests of the repaired part of the shaft were to confirm the lack of stress accumulation in the part of the shaft where the repair was done.

The purpose of the performed measurements of temperature distribution in the machine shaft in the area of the passage to the flange used to connect the shaft to the hoist drum [10] was to determine any changes in the temperature in this spot. An FLIR P660 thermovision camera with a tripod was used for the inspection. The recorded results of the inspection were compared with the results recorded for the same machine on October 23, 2010; that is, before the breakdown [11]. Figure 10 shows the sample thermogram of the part of the drive shaft and of the disk of the drive wheel.

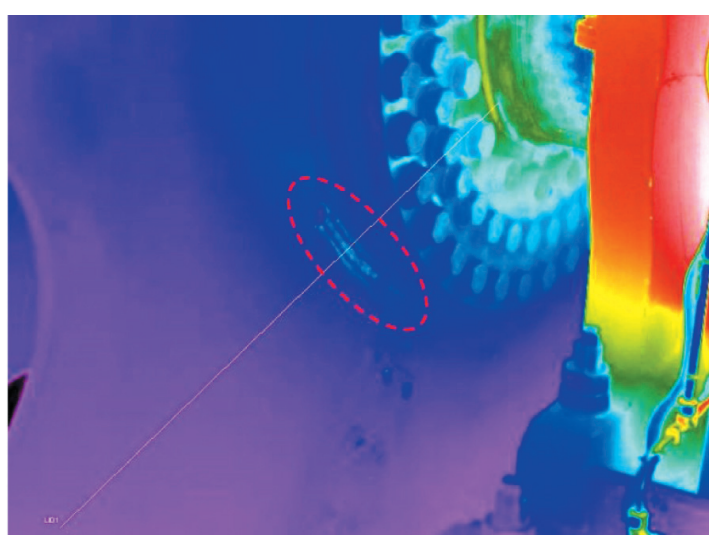

Fig. 10. Thermogram of part of drive shaft and of disk of drive wheel from southeastern side ("rain" pallet) [10]

The thermovision measurements showed a lack of significant temperature differences of the analyzed driving structure (the shaft - the hoist drum). No major 
differences were recorded against the measurements before the breakdown. The average temperatures of the shaft in both measurements differed due to the differences in the ambient temperature during the measurements. For this reason, the differences in the temperatures were more important at the passage from the cylinder part of the shaft to the flange to the connection with the hoist drum. The temperature difference was about $5.3^{\circ} \mathrm{C}$. One should remember that the measurements could be burdened with measurement uncertainty resulting from the different emissivity factors for the different examined structures, flow of warm and cold masses of air forced by the fans of the motors, vibrations of the tower that may have negatively affected the thermovision camera, effect of the reflection of radiation from other sources of heat, etc.

Both extensometric and thermovision inspections showed the lack of a clear increase in the concentration of local stresses (the notch effect) in the examined area of the shaft after its repair.

\section{PARAMETERS OF OPERATION OF MACHINE WITH REPAIRED SHAFT}

After finding that the shaft after the repair did not show clear defects, documentation of the parameters of operation of the machine with the repaired shaft was started until the time of execution of the new shaft.

The shaft was made of E335 steel with the following values of strength properties:

- yield point

$R_{e l}=280 \mathrm{~N} / \mathrm{mm}^{2}$,

- temporary tensile strength

$R_{m}=590 \mathrm{~N} / \mathrm{mm}^{2}$,

- limit substitute allowed stress

taking into consideration

permanent fatigue strength $\quad R_{\text {limit }}=50 \mathrm{~N} / \mathrm{mm}^{2}$.

The damage of the cross section was found in the place of the base of the eastern flange of the shaft, with the two halves of the side disk of the hoist drum fixed with three rows of bolts. In the strength calculations of the shaft [12], it is the cross section with the diameter of $\phi 685 \mathrm{~mm}$ with the following coefficients: bending strength $W_{g}=31,555,249 \mathrm{~mm}^{3}$; torsion strength $W_{s}=63,110,498 \mathrm{~mm}^{3}$. The maximum calculated accident stresses for the given case of load are as follows (respectively):
- normal load
$\sigma_{e}=30.87 / \mathrm{mm}^{2}$,
- exceptional load
$\sigma_{e}=179.96 / \mathrm{mm}^{2}$.

It was assumed, however, that the completed repair of the damaged cross section of the shaft cancause a decrease in the general load capacity of the shaft of an estimated value of ca. 30\%. Therefore, the reduction of the technical parameters of the operation of the hoisting machine after the repair was proposed up to the following values:

- actual usable mass

$25,000 \mathrm{~kg}$,

- extraction speed

$12 \mathrm{~m} / \mathrm{s}$,

- travel acceleration and delay

$0.5 \mathrm{~m} / \mathrm{s}^{2}$.

For such assumed parameters, the strength calculations of the shaft were done, achieving the following maximum calculated accident stresses for normal load $\sigma_{e}=21.20 \mathrm{~N} / \mathrm{mm}^{2}$. Exceptional load causes stress of an unchanged value against the condition before the repair. The reduction of the values of the operational parameters of the machine will cause the reduction of stress in the repaired cross section by $9.67 \mathrm{~N} / \mathrm{mm}^{2}$; i.e., by $31.32 \%$. The limitations of the travel parameters of the hoisting machine (in particular, acceleration and delay to a value of $0.5 \mathrm{~m} / \mathrm{s}^{2}$ ) will cause a major limitation in the value of the dynamic moment, which is decisive for the fatigue process of the structural elements of the machine.

The strength analysis of the shaft submitted by the producer of the shaft, drafted up with the finite element method (FEM) with the assumed operational parameters of the hoisting machine after the repair of the shaft also showed the acceptable level of stresses, confirming the results of the traditional strength calculations. The reduced values of the proposed operational parameters after the repair of the shaft resulted in ca. $40 \%$ reduction in the maximum value of the moment from the overweight in the condition of acceleration of the travel of the machine; i.e., from $1766 \mathrm{kNm}$ to $1046 \mathrm{kNm}$. It was the significant reduction of the load with the moment of the flange of the shaft in the situation when the load-bearing cross section of the base of the flange of the shaft was damaged. The consequence of the reduction of the operational parameters of the hoisting machine also came in the form of an increase in the strength excess of the connection of the flange of the shaft with the side disk of the hoist drum from a value of 5.62 to 9.49 .

It was found that the repair had not caused the material notch that may develop in the case of a significant difference in the hardness in a small area of the element. It is another premise proving that, after the repair and limitation of the load, the further operational use of the shaft is possible. 
Considering:

- the assessment of correctness of the technology and execution of the repair of the shaft;

- the estimated assessment of load-bearing capacity of the executed connection;

- the results of the classic strength calculations of the shaft;

- the strength analysis of the shaft provided with the FEM method.

In reference to the above considerations, the decision was made on allowing for the time-limited (up to six months after the time of repair) operational use of the hoisting machine with limited travel parameters until the execution of the new shaft. The internal cross section of the base of the flange of the shaft (where the crack probably started) was invisible from the inside of the hoist drum, as it was covered by the (eastern) side disc of the hoist drum. For this reason, after arrangement with the designer of the shaft, for the inspection of this cross section, three openings were executed in each half of the side disk of the hoist drum to enable a visual or technical inspection of this cross section. The visual inspection of the cross section of the base of the flange of the shaft from the eastern bearing side was fully possible all the time. Due to the accessibility, this cross section could be inspected with the available technical methods.

Control arrangements:

- continuous visual inspection of a properly prepared employee of the area of the shaft of the hoisting machine between the case of the eastern bearing and the flange of the shaft was recommended; this inspection was important due to the fact that the operators do not have visual contact with the machines in the tower of the R-II shaft;

- after each shift, visual inspection of the repaired cross section should be done by entering the interior of the hoist drum through the openings and providing good lighting; the inspection should also cover the western flange of the shaft;

- in the first three weeks of the operation of the machine after the repair, inspections should be done as often as possible, minimum after each shift, as well as during the technological stopping of the hoisting machine;

- after three weeks of operation of the machine, the inspections of the repaired cross section should be conducted once per shift;
- the revisions of the area of the repaired shaft should be conducted following the effective regulations of safety of work.

\section{SUMMARY AND CONCLUSIONS}

As a result of the breakdown, the R-II mining shaft hoist in the southern section was out of operation for 27 days (April 17, 2011, through May 13, 2011). The hoisting machine was operated during the next 118 days (until September 8, 2011) with limited travel parameters (ca. $54 \%$ of the nominal capacity). From September 8, 2011, until September 16, 2011, the shaft was replaced with a new one with a different design.

The breakdown related to the crack of the flange of the shaft caused the total losses in the extraction of copper ore estimated (according to the ZG Rudna data) at 43, 240 skips (1,362,060 Mg). Additionally, due to the emergency stopping of the R-II S mining shaft hoist, changes were necessary in the logistics of deliveries of ore to O/ZWR Rejon Polkowice i Rudna. One should remember that the losses would be significantly higher had the repair of the shaft of the hoisting machine in the southern section of the R-II shaft not been successfully provided.

\section{References}

[1] Opinion on inspections and assessment of the emergency repair of the shaft along with statement of the technical parameters of further operational use of the hoisting machine $4 \mathrm{~L}-5500 / 2 \times 3600$ in the R-II shaft in the southern section KGHM Polska Miedź S.A. Oddział ZG “Rudna” Drawn up by the team headed by dr hab. inż. Marian Wójcik, prof. AGH, Krakow, 11 May 2011.

[2] Inspection results no. 114/11/N/Ł of 17.04.2011. Zespół Rzeczoznawców Urządzeń Technicznych “Autorytet” Sp. z o.o., Polkowice, ul. Kopalniana 1.

[3] Decision of Urząd Górniczy do Badań Kontrolnych Urządzeń Energomechanicznych, ref. UGB/0232/0001/11/01520/Sz. 2011.

[4] Welding repair guidelines for the crack in the flange of the main shaft of the hoisting machine in the R-II shaft in the southern section in O/ZG "Rudna" KGHM Polska Miedź S.A. Instytut Spawalnictwa, Gliwice 2011.

[5] Description of the technology of heating up for welding of the machine shaft. Firma LMS s.c. T. Macioła i K. Scheithauer, Chorzów, ul. Wieniawskiego 18, 2011.

[6] Report from the repair by welding of the crack at the flange of the main shaft of the hoisting machine in the R-II shaft in the southern section in O/ZG "Rudna" KGHM Polska Miedź S.A. along with the Welding Guide W/P/Z/11 and Material Attestations. Warexim Przedsiebiorstwo Wielobranżowe Aleksander Warsz, 44-114 Gliwice, ul. Czajki 11/38, 2011.

[7] Shaft heating up technology. Firma LMS s.c. T. Macioła i K. Scheithauer, Chorzów, ul. Wieniawskiego 18, 2011. 
[8] Inspection results no. 138/11/N/ . Ultrasonic tests of the shaft of the hoisting machine $4 \mathrm{~L}-5500 / 2 \times 3600$ in the R-II shaft in the southern section. "Autorytet", Polkowice, 10.05.2011.

[9] Inspection results no. 139/11/N/ $\mathbb{E}$ - Non-destructive inspections of the shaft of the hoisting machine $4 \mathrm{~L}-5500 / 2 \times 3600$ in the R-II shaft in the southern section. "Autorytet", Polkowice, 10.05.2011.

[10] Extensometric measurements of stresses in the design of the drive wheels along with the analysis of results in the hoisting machines of mining hoist units in the R-II shaft KGHM Polska Miedź S.A. O/ZG “Rudna”. Katedra Transportu Linowego AGH, Krakow, June 2010.

[11] Inspections and assessment of the drive wheel in the hoisting machines of the mining hoisting units in the R-II shaft KGHM Polska Miedź S.A. O/ZG “Rudna”. Katedra Transportu Linowego AGH, Kraków, October 2010.
[12] Documentation with the application for approval of operational use of the hoisting machine 4L-5500/2 $\times 3600$ by $\mathrm{ABB}$, the R-II shaft, the southern and northern sections, KGHM Polska Miedź S.A. Oddział ZG "Rudna", no. 3BPC001189D0144, vol. 1 and 2.

TOMASZ ROKITA, Ph.D., Eng.

Department of Rope Transport

Faculty of Mechanical Engineering and Robotics AGH University of Science and Technology

al. Mickiewicza 30,

30-059 Krakow, Poland rokitom@agh.edu.pl 


\title{
Awaria maszyny wyciągowej górniczego wyciągu szybowego zainstalowanego w przedziale południowym szybu R-II KGHM Polska Miedź S.A. O/ZG Rudna
}

\begin{abstract}
Niniejszy artykut dotyczy bezprecedensowego przypadku częściowego pęknięcia watu głównego maszyny wyciagowej, jaki miat miejsce w przedziale południowym szybu R-II KGHM Polska Miedź S.A. Oddziat ZG „Rudna” w 2011 r. Górnicze wyciagi szybowe zainstalowane w szybie R-II sa podstawowymi urzadzeniami wydobywczymi nie tylko w kopalni Rudna, ale i w calym KGHM. Nieplanowane postoje tych wyciagów generuja milionowe straty dla kopalni. Powody te zdecydowaty o konieczności doraźnej naprawy uszkodzonego watu i eksploatacji wyciagu do czasu wykonania i dostarczenia nowego watu.

$W$ artykule opisano prace zwiazane z przygotowaniem $i$ wykonaniem naprawy watu oraz badania przeprowadzone po naprawie. Ostatnim etapem prac było opracowanie warunków eksploatacji watu maszyny z naprawionym wałem z ograniczonymi parametrami kinematycznymi i pod ścistym nadzorem obstugi do czasu wykonania nowego wału.
\end{abstract}

Słowa kluczowe: górniczy wyciag szybowy, wał główny, awarie maszyn wyciagowych

\section{WPROWADZENIE}

Górnicze wyciągi szybowe zabudowane w szybie R-II przeznaczone są do ciągnienia urobku w skipach o udźwigu $33 \mathrm{Mg}$. Po trzydziestu latach intensywnej eksploatacji (od 1974 r.) przystąpiono do ich kompleksowej modernizacji. Maszynę wyciągową w przedziale południowym (S) szybu R-II zmodernizowano w styczniu 2004 r, a maszynę wyciągową w przedziale północnym (N) R-II w maju 2006 r. Modernizacja polegała na wymianie części mechanicznej maszyn tzn. wału głównego, linopędni, łożysk i układ hamulców wraz ze sterowaniem.

Maszyna przystosowana jest do sterowana automatycznego oraz sterowania ręcznego przez maszynistę wyciągowego.

Dane charakterystyczne maszyny wyciągowej deklarowane w dokumentacji:

- średnica linopędni $5500 \mathrm{~mm}$,

- nominalna średnica lin nośnych

- liczba lin nośnych

- maksymalna nadwaga statyczna
- maksymalna siła statyczna w czterech linach nośnych

- siła zrywająca cztery liny nośne

- maksymalna prędkość ciągnienia urobku

$1200 \mathrm{kN}$, $4 \cdot 2130 \mathrm{kN}$,

$20 \mathrm{~m} / \mathrm{s}$.

Linopędnia maszyny wyciągowej osadzona jest na wale głównym spoczywającym w dwóch łożyskach tocznych po obu jej stronach. Łożyska smarowane są olejem, ciśnieniowo w obiegu zamkniętym. Na obydwu swobodnych końcach wału nałożone są wirniki silników napędowych. Napęd maszyny wyciągowej stanowią dwa obcowzbudne silniki prądu stałego PW-106 o mocy 3600 kW każdy, zasilane z przekształtników tyrystorowych serii DCA 600.

Hamulec składa się z czterech stojaków hamulcowych z szesnastoma parami siłowników (po cztery na każdym ze stojaków) i zespołu sterowniczo-zasilającego składającego się z dwóch agregatów hydraulicznych, z których jeden stanowi rezerwę. Łożyska wału głównego, stojaki hamulcowe, stojany silników napędowych i urząadzenie do obróbki rowków linowych posadowione są na stalowej konstrukcji wieży wyciągowej. 
Maszyna wyciągowa w części mechanicznej składa się z wału głównego spoczywającego w dwóch łożyskach tocznych, linopędni dostosowanej do współpracy z czterema linami wyciągowymi nośnymi, hamulca oddziałującego na dwie tarcze hamulcowe, składającego się z czterech stojaków, na których zamocowane są po cztery pary hydraulicznie odwodzonych siłowników hamulcowych sterowanych dwuagregatowym zespołem sterowniczo-zasilającym, dwóch silników napędowych oraz urządzenia do obróbki rowków linowych.

Do nadzorowania i kontroli ruchu maszyny zastosowane są nadajniki impulsów połączone $\mathrm{z}$ wałem głównym, tj.:

- pulsogenerator zabudowany z jednej strony wału,

- tachoprądnica $\mathrm{z}$ pulsogeneratorem zabudowane $\mathrm{z}$ drugiej strony wału.

Natomiast do kontrolowania ruchu naczyń wyciągu szybowego zastosowano pulsogenerator napędzany od osi wału kół linowych odciskowych.

Oba agregaty hydrauliczne zespołu sterowniczozasilającego hamulca usytuowane są na poziomie maszyny wyciągowej. Na rysunku 1 zamieszczono widok maszyny w przedziale $(S)$ po modernizacji.

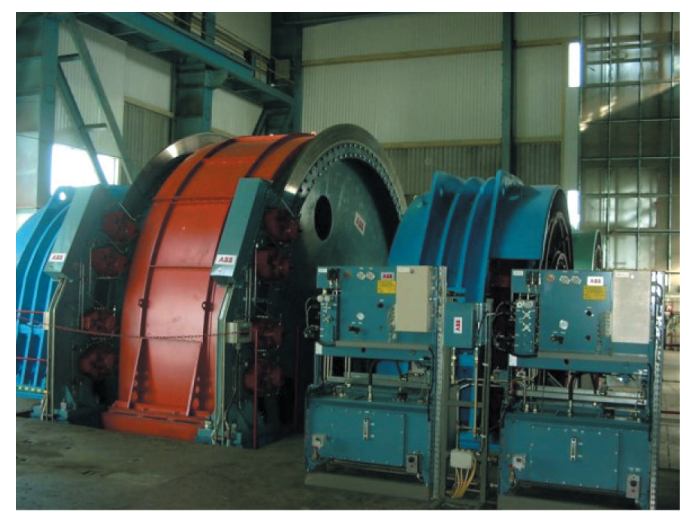

Rys. 1. Widok maszyny wyciagowej $w$ przedziale (S) szybu R-II po modernizacji w 2004 r. [1]

W dniu 17.04.2011 r. obsługa wyciągu zaobserwowała uszkodzenie wału maszyny wyciągowej w przedziale południowym $\mathrm{w}$ rejonie przejścia wału w kołnierz służący do połączenia $\mathrm{z}$ linopędnią po stronie wschodniej.

Pęknięcie, jak również miejscami odpryski materiału, były widoczne na długości około połowy obwodu wału. Charakter uszkodzenia wskazywał na pęknięcie zmęczeniowe (rys. 2 i 3 ).

Ze względu na możliwość dostępu do miejsca uszkodzenia jedynie od strony łożyska wału (wschodniej) dokładna ocena uszkodzenia była możliwa dopiero po demontażu linopędni i wykonaniu specjalistycznych badań metodą wizualną i magnetyczno-proszkową. Badania te zostały wykonane w dniu 17.04.2011 r. przez rzeczoznawcę z firmy Autorytet Spółka z o.o. [2].

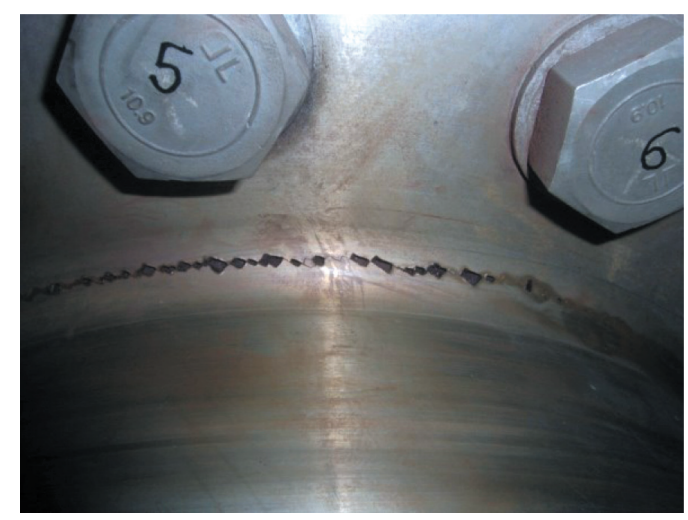

Rys. 2. Pęknięcia po obwodzie z wykruszeniem [1]

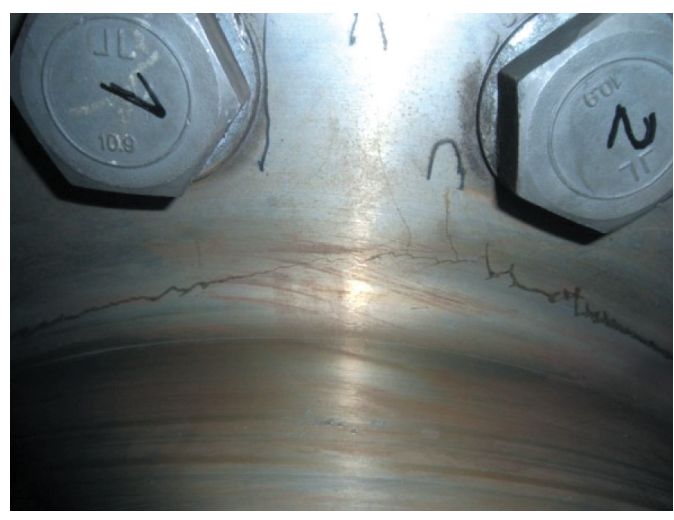

Rys. 3. Pęknięcia po obwodzie oraz pęknięcia promieniowe [1]

$\mathrm{Na}$ podstawie wykonanych badań sporządzono między innymi rysunek $4 \mathrm{z}$ zaznaczeniem rozpoznanych uszkodzeń.

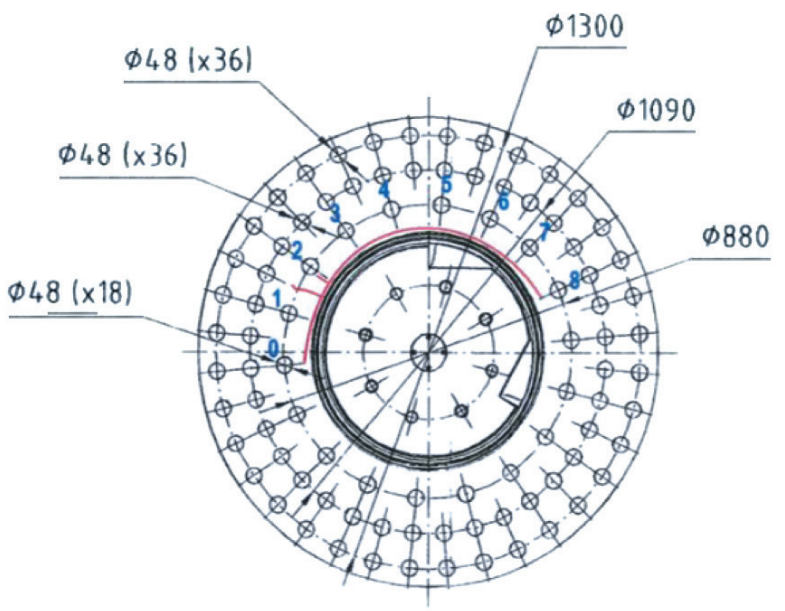

Rys. 4. Tarcza boczna linopędni maszyny wyciagowej $w$ przedziale południowym (od strony wschodniej) z zaznaczonymi pęknięciami (kolor czerwony) [2] 
W wyniku badania stwierdzono:

- pęknięcie po obwodzie o długości 1000 mm w kierunku osiowym (równolegle do osi wału) na wskroś materiału;

- pęknięcie z wykruszeniem materiału o długości 〜60 mm w kierunku osiowym na wskroś materiału;

- dwa pęknięcia promieniowe (prostopadle do osi wału) od obwodowego o długości $\sim 100 \mathrm{~mm} \mathrm{i} \sim 60 \mathrm{~mm}$ pomiędzy śrubami nr 1 i 2.

Stwierdzone uszkodzenia nie pozwalały na dalszą eksploatację maszyny wyciągowej. Konsekwencją ww. badań była Decyzja Dyrektora Urzędu Górniczego do Badań Kontrolnych Urządzeń Energomechanicznych wstrzymująca ruch zakładu górniczego w części dotyczącej górniczego wyciągu szybowego zainstalowanego w przedziale południowym szybu R-II O/ZG Rudna [3].

\section{KONCEPCJA NAPRAWY WAKU}

Naprawę pękniętego wału zdecydowano się wykonać metodą spawania według technologii opracowanej przez Instytut Spawalnictwa w Gliwicach i uzgodnionej z ZG Rudna [4]. Z uwagi na rozległy ubytek materiału kołnierza konieczne było przygotowanie rowka spawalniczego, czyli wykonanie odpowiednich podcięć (geometrii) elementów łączonych (rys. 5). Po przygotowaniu brzegów rowka spawalniczego przeprowadzono badania penetracyjne (pod kątem wykrycia ewentualnych pęknięć).

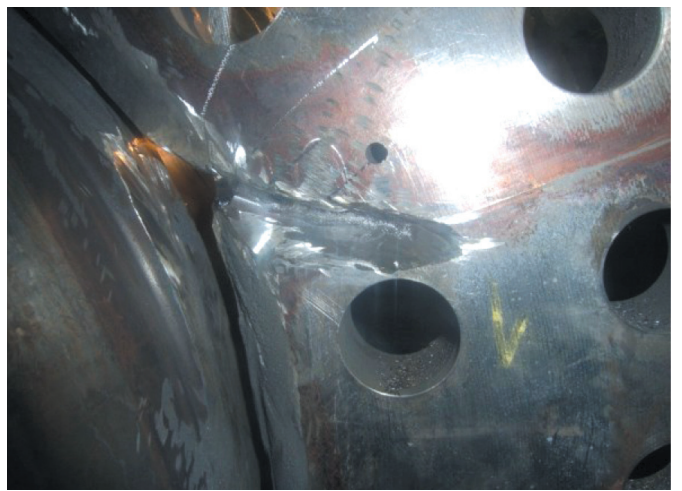

Rys. 5. Przebieg naprawy. Przygotowanie rowka spawalniczego z uwagi na grubość kotnierza i wielkość pęknięcia [1]

Obszar wokół miejsca naprawy został odizolowany, a następnie podgrzany do temperatury około $100^{\circ} \mathrm{C}$ za pomoca nagrzewarki oporowej oraz mat grzewczych z szybkością około $25^{\circ} \mathrm{C}$ na godzinę. Po ustabilizowaniu się temperatury na wale i kołnierzu przystapiono do wykonywania prac spawalniczych, jednocześnie prowadząc ciągłą rejestrację temperatury elementów sąsiadujących $\mathrm{z}$ miejscem spawania (rys. 6). Szczególną uwagę zwracano na utrzymanie w odpowiednim zakresie różnicy temperatur elementów łożyska podtrzymującego wał [5-7].

Aby uchronić łożysko toczne przed możliwym uszkodzeniem wskutek rozszerzalności cieplnej podgrzewano obudowę łożyska tak, aby różnica temperatury między bieżnią wewnętrzną i zewnętrzną nie przekroczyła $15^{\circ} \mathrm{C}$.

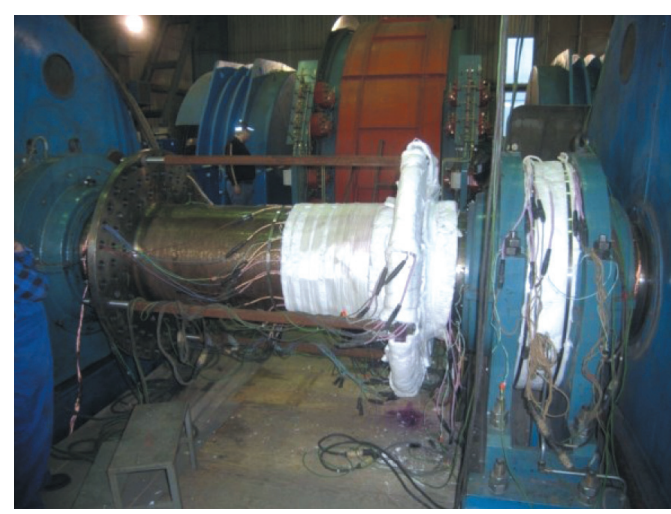

Rys. 6. Obszar wokót miejsca spawania zostat odizolowany, a nastęnie podgrzany za pomoca nagrzewarki oporowej oraz mat grzewczych; prędkość nagrzewania wynosita około $25^{\circ} \mathrm{C}$ na godzine [1]

Ze względu na to, że materiał, z którego wykonano wał, należy do stali trudno spawalnych, a także z uwagi na rozmiar uszkodzenia proces spawania przeprowadzano dwuetapowo. W pierwszej kolejności wykonano warstwę buforową od strony wału oraz kołnierza. Następnie odpowiednio wyrównano powierzchnię warstwy buforowej za pomocą szlifowania oraz przystąpiono do wypełniania rowka spawalniczego zgodnie z przygotowaną wcześniej instrukcją (rys. 7). Na rysunku 8 przedstawiono widok fragmentu wału w rejonie pęknięcia po nałożeniu warstwy buforowej.

Kolejnym etapem było łączenie kołnierza z wałem (zamykanie spoiny). Jako spoiwo wykorzystano drut ENiCrFe-3 według AWS A 5.11. Po połaczeniu kołnierza $\mathrm{z}$ wałem wypełniono cały rowek spawalniczy oraz nałożono naddatek na obróbkę skrawaniem (rys. 9).

$\mathrm{Na}$ każdym etapie prac spawalniczych były wykonywane badania penetracyjne. W przypadku wykrycia pęknięć materiał szlifowano aż do ich usunięcia, a dopiero potem kontynuowano prace spawalnicze. Materiały dodatkowe zastosowane do spawania zo- 
stały dobrane w taki sposób, aby umożliwić wykonanie połączenia trudno spawalnego materiału, z którego wykonano wał, oraz aby uzyskać własności stopiwa jak najbardziej zbliżone do własności materiału rodzimego wału. Prace spawalnicze związane $\mathrm{z}$ naprawą wału były wykonywane bez przerwy (dzień i noc) przez mniej więcej tydzień.

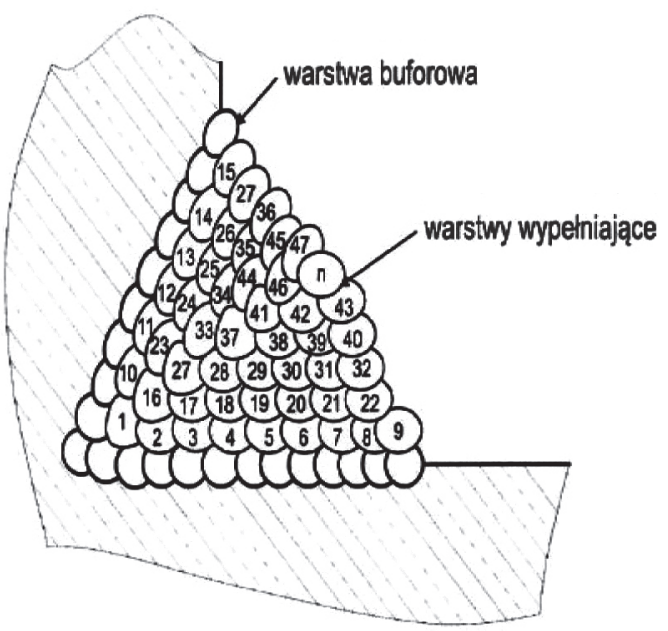

Rys. 7. Kolejność wykonywania prac spawalniczych: warstwy buforowej $i$ warstwy wypetniajacej [4]

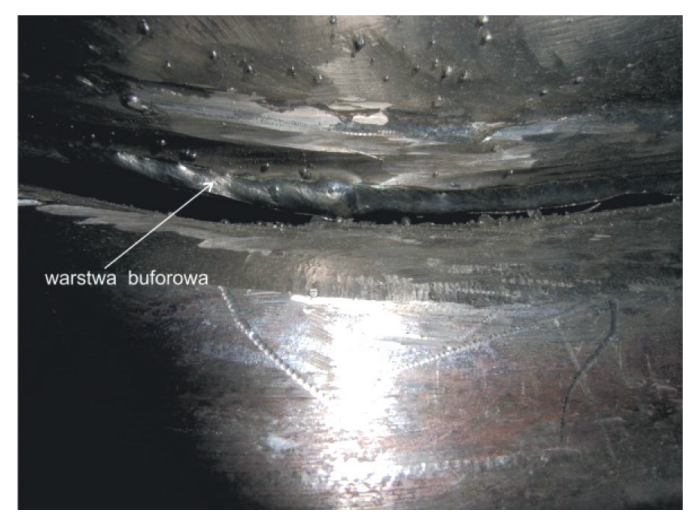

Rys. 8. Widok wału po natożeniu warstwy buforowej [1]

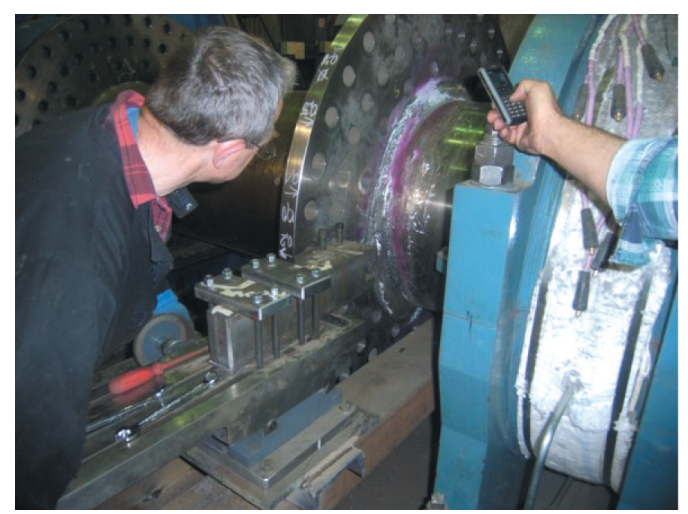

Rys. 9. Obróbka watu po spawaniu w celu nadania fragmentowi watu odpowiedniego promienia krzywizny [1]

\section{BADANIA WAtU MASZYNY PO WYKONANEJ NAPRAWIE}

Po wykonaniu naprawy przeprowadzono badania wału maszyny w celu potwierdzenia gotowości naprawionego wału do dalszej eksploatacji. Badania wykonywane były między innymi przez rzeczoznawców z firmy Autorytet Spółka z o.o. [8, 9] (badania nieniszczące wału) oraz pracowników Katedry Transportu Linowego AGH w Krakowie (badania naprężeń). Wykonane przez KTL-AGH badania tensometryczne naprężeń w części cylindrycznej wału oraz w kołnierzu łączącym go z linopędnią oraz badania termowizyjne naprawionego fragmentu wału [10] miały stwierdzić brak kumulowania się naprężeń w częściach wału objętych naprawą.

Z kolei celem wykonywanych pomiarów rozkładu temperatury na wale maszyny $\mathrm{w}$ rejonie przejścia w kołnierz służący do łączenia wału z linopędnią było określenie zmian temperatury w tym węźle. Do badań wykorzystano kamerę termowizyjną FLIR P660 wraz ze statywem. Zarejestrowane wyniki badań porównano $\mathrm{z}$ wynikami zarejestrowanymi na tej samej maszynie 23 października 2010 r., a więc jeszcze przed awarią [11]. Na rysunku 10 pokazano przykładowy termogram fragmentu wału napędowego i tarczy koła pędnego.

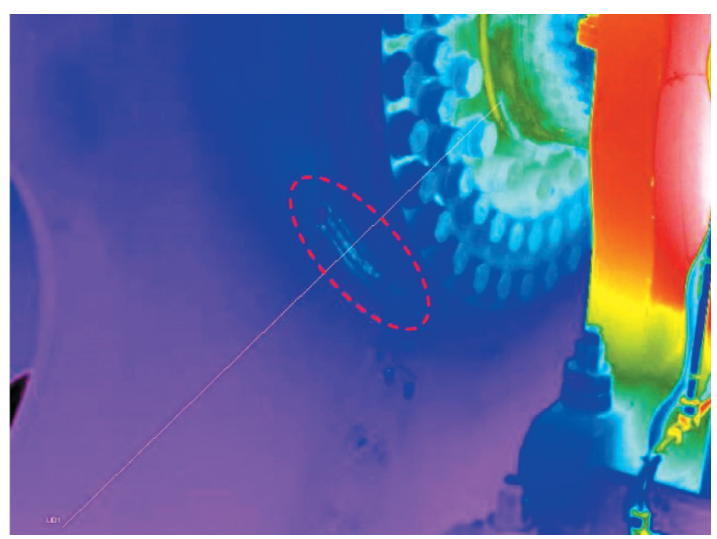

Rys. 10. Termogram fragmentu watu napędowego i tarczy koła pędnego od strony potudniowo-wschodniej (paleta „rain”) [10]

Pomiary termowizyjne wskazały na brak istotnie dużych różnic temperaturowych badanej struktury napędowej (wał - linopędnia). W odniesieniu do wyników pomiarów sprzed awarii też nie zanotowano większych różnic. Średnie temperatury wału obu pomiarów różniły się z powodu różnic w temperaturze otoczenia podczas wykonywania pomiarów. 
Dlatego ważniejsze były różnice temperatur przy przejściu z części walcowej wału w kołnierz do połączenia z linopędnią. Różnica temperatur wynosiła około $5,3^{\circ} \mathrm{C}$. Należy mieć na uwadze to, że pomiary mogły być obarczone niepewnością pomiarową wynikającą między innymi z różnych współczynników emisyjności dla różnych badanych struktur, przepływem ciepłych i zimnych mas powietrza wymuszonym przez wentylatory silników, drganiami wieży mogącymi wpływać niekorzystnie na kamerę termowizyjną, wpływem odbicia promieniowania pochodzącego od innych źródeł ciepła itp.

Zarówno badania tensometryczne, jak i termowizyjne wskazały brak wyraźnego zwiększenia koncentracji naprężeń lokalnych (wpływu karbu) w badanym rejonie wału po jego naprawie.

\section{PARAMETRY PRACY MASZYNY Z NAPRAWIONYM WAŁEM}

Po stwierdzeniu, że wał po naprawie nie wykazuje wyraźnych usterek, przystąpiono do opracowania parametrów pracy maszyny z naprawionym wałem do chwili wykonania nowego wału.

Wał wykonano ze stali E335 o następujących parametrach własności wytrzymałościowych:

- granica plastyczności $R_{e l}=280 \mathrm{~N} / \mathrm{mm}^{2}$,

- doraźna wytrzymałość

na rozciąganie

$R_{m}=590 \mathrm{~N} / \mathrm{mm}^{2}$,

- graniczne zastępcze

naprężenie dopuszczalne

uwzględniające trwałą

wytrzymałość zmęczeniową $R_{\text {limit }}=50 \mathrm{~N} / \mathrm{mm}^{2}$.

Stwierdzono, że uszkodzenie przekroju nastąpiło w miejscu nasady kołnierza wschodniego wału, do którego trzema rzędami śrub mocowane sa dwie połówki tarczy bocznej linopędni. W obliczeniach wytrzymałościowych wału [12] jest to przekrój o średnicy $\$ 685 \mathrm{~mm}$ o wskaźnikach: wytrzymałości na zginanie $W_{g}=31555249 \mathrm{~mm}^{3}$, na skręcanie $W_{s}=$ $=63110498 \mathrm{~mm}^{3}$. Maksymalne obliczeniowe naprężenia zredukowane dla danego przypadku obciążenia wynoszą odpowiednio:

- obciążenia w warunkach eksploatacyjnych $\sigma_{e}=30,87 \mathrm{~N} / \mathrm{mm}^{2}$,

- obciążenia wyjątkowe w warunkach awaryjnych
Założono, że wykonana naprawa uszkodzonego przekroju wału może jednak spowodować spadek ogólnej nośności wału o szacunkową wartość około 30\%. Dlatego też zaproponowano zmniejszenie parametrów ruchowych pracy maszyny wyciągowej po naprawie do wartości:

- masa użyteczna rzeczywista

$25000 \mathrm{~kg}$,

- prędkość dla wydobycia

$12 \mathrm{~m} / \mathrm{s}$,

- przyspieszenie

i opóźnienie ruchowe $\quad 0,5 \mathrm{~m} / \mathrm{s}^{2}$.

Po przyjęciu powyższych parametrów wykonano obliczenia wytrzymałościowe wału, uzyskując następujące maksymalne obliczeniowe naprężenia wypadkowe dla obciążenia w warunkach eksploatacyjnych $\sigma_{e}=21,20 \mathrm{~N} / \mathrm{mm}^{2}$. Obciążenie wyjątkowe w warunkach awaryjnych wywołuje naprężenie o niezmienionej wartości w stosunku do stanu przed naprawą. Zmniejszenie wartości parametrów pracy maszyny spowoduje zmniejszenie naprężenia w przekroju naprawianym o $9,67 \mathrm{~N} / \mathrm{mm}^{2}$, tj. o $31,32 \%$. Ograniczenie parametrów ruchowych maszyny wyciągowej, a szczególnie przyspieszenia i opóźnienia do wartości $0,5 \mathrm{~m} / \mathrm{s}^{2}$ spowoduje znaczne ograniczenie wartości momentu dynamicznego, który ma decydujący wpływ na proces zmęczenia elementów konstrukcyjnych maszyny.

Przedłożona przez firmę projektującą wał analiza wytrzymałościowa wału, wykonana metodą elementów skończonych (MES), przy założonych parametrach pracy maszyny wyciągowej po naprawie wału wykazała również akceptowalny poziom naprężeń, potwierdzając wyniki tradycyjnych obliczeń wytrzymałościowych. Obniżone wartości proponowanych parametrów ruchowych po naprawie wału skutkowały obniżeniem o około $40 \%$ maksymalnych wartości momentu pochodzącego od nadwagi w stanie przyspieszenia ruchu maszyny, tj. z $1766 \mathrm{kNm}$ do $1046 \mathrm{kNm}$. Było to istotne zmniejszenie obciążenia momentem kołnierza wału, w sytuacji kiedy uszkodzeniu uległ przekrój nośny podstawy kołnierza wału. Konsekwencją zmniejszenia parametrów ruchowych maszyny wyciągowej było również zwiększenie nadmiaru wytrzymałościowego śrubowego połączenia kołnierza wału z tarczą boczną linopędni z wartości 5,62 do 9,49 .

Stwierdzono, że wykonana naprawa nie spowodowała powstania karbu materiałowego, który może nastąpić w przypadku znacznej różnicy twardości 
na niewielkim obszarze elementu. Jest to kolejna przesłanka świadcząca o tym, że po naprawie i ograniczeniu obciążenia dalsza eksploatacja wału jest możliwa.

Wzięto pod uwagę:

- ocenę poprawności technologii i wykonania naprawy wału,

- szacunkową ocenę nośności wykonanego połączenia,

- wyniki klasycznych obliczeń wytrzymałościowych wału,

- analizę wytrzymałościową wału wykonaną metodą elementów skończonych.

W związku z powyższym podjęto decyzję zezwalającą na ograniczoną czasowo (do sześciu miesięcy od chwili przeprowadzenia naprawy) eksploatację maszyny wyciągowej przy ograniczonych parametrach ruchu do momentu wykonania nowego wału. Wewnętrzny przekrój nasady kołnierza wału, gdzie prawdopodobnie rozpoczęło się pęknięcie, był niewidoczny od wewnątrz linopędni, ponieważ zasłaniała go tarcza boczna (wschodnia) linopędni. Dlatego, w celu kontroli tego przekroju, po uzgodnieniu z konstruktorem wału wykonano w każdej połówce tarczy bocznej linopędni po trzy otwory pozwalające wzrokowo lub dostępną technicznie metodą kontrolować ten przekrój. Wizualna kontrola przekroju nasady kołnierza wału od strony łożyska wschodniego była cały czas w pełni możliwa. Przekrój ten można było kontrolować dostępnymi technicznie metodami.

Ustalenia dotyczące kontroli:

- zalecono ciągłą kontrolę wzrokową odpowiednio przygotowanego pracownika, rejonu wału maszyny wyciągowej pomiędzy obudową łożyska wschodniego a kołnierzem wału; była ona istotna ze względu na to, że maszyniści nie widzą maszyn na wieży szybu R-II;

- po każdej zmianie, po wejściu do wnętrza linopędni przy dobrym oświetleniu przez wykonane otwory, zalecono kontrolować wzrokowo stan naprawianego przekroju; kontroli powinien zostać poddany także kołnierz zachodni wału;

- przez okres pierwszych trzech tygodni pracy maszyny po naprawie zalecono, aby kontrole były wykonywane możliwie często - minimum po każdej zmianie, a również podczas technologicznych zatrzymań maszyny wyciągowej;
- po trzech tygodniach pracy maszyny zalecono przeprowadzanie kontroli naprawianego przekroju raz na zmianę;

- rewizje rejonu naprawianego wału powinny być przeprowadzane z zastosowaniem obowiązujących przepisów bezpieczeństwa pracy.

\section{PODSUMOWANIE I WNIOSKI}

W wyniku zaistniałej awarii górniczy wyciąg szybowy R-II w przedziale południowym był wyłączony z eksploatacji przez dwadzieścia siedem dni (od 17.04.2011 r. do 13.05.2011 r.). Przez kolejne sto osiemnaście dni (do 08.09.2011 r.) wyciąg był eksploatowany przy ograniczonych parametrach ruchowych (do około 54\% swojej nominalnej wydajności). W dniach od 08.09.2011 r. do 16.09.2011 r. przeprowadzono wymianę wału na nowy o zmienionej konstrukcji.

Awaria związana z pęknięciem kołnierza wału spowodowała łączne straty w wydobyciu rudy miedzi oszacowane (według danych z ZG Rudna) na 43240 skipów (1 $362060 \mathrm{Mg}$ ). Dodatkowo w związku z awaryjnym zatrzymaniem górniczego wyciągu szybowego R-II S konieczne były zmiany w logistyce dostaw rudy do O/ZWR Rejon Polkowice i Rudna. Należy zwrócić uwagę, że gdyby nie pomyślnie przeprowadzona naprawa wału maszyny wyciągowej przedziału południowego szybu R-II, powstałe straty byłyby znacznie większe.

\section{Literatura}

[1] Opinia dotycząca badań i oceny awaryjnej naprawy wału wraz z określeniem parametrów technicznych dalszej eksploatacji maszyny wyciągowej 4L-5500/2×3600 szybu R-II przedział południowy KGHM Polska Miedź S.A. Oddział ZG „Rudna” oprac. zespół pod kierunkiem dr hab. inż. Mariana Wójcika, prof. AGH, Kraków, 11 maja 2011 r.

[2] Wyniki badania $\mathrm{Nr}$ 114/11/N/E z dn. 17.04.2011 r., oprac. Zespół Rzeczoznawców Urządzeń Technicznych „Autorytet”Sp. z o.o., Polkowice, ul. Kopalniana 1.

[3] Decyzja Urzędu Górniczego do Badań Kontrolnych Urządzeń Energomechanicznych L. dz. UGB/0232/0001/11/ 01520/Sz.

[4] Wytyczne naprawy za pomocą spawania pęknięcia na kołnierzu wału głównego maszyny wyciągowej szybu R-II przedział południowy w O/ZG „Rudna” KGHM Polska Miedź S.A., Instytut Spawalnictwa, Gliwice.

[5] Opis technologii podgrzewania do spawania wału maszyny Firma LMS s.c. T. Macioła i K. Scheithauer, Chorzów, ul. Wieniawskiego 18.

[6] Sprawozdanie z naprawy za pomocą spawania pęknięcia znajdującego się na kołnierzu wału głównego maszyny wyciągowej szybu R-II przedział południowy w O/ZG „Rudna” KGHM Polska Miedź S.A. wraz z instrukcją technologiczną spawania W/P/Z/11 i atestami materiałowymi, Warexim Przedsiębiorstwo Wielobranżowe Aleksander Warsz, ul. Czajki 11/38, 44-114 Gliwice. 
[7] Technologia podgrzewania wału, Firma LMS s.c. T. Macioła i K. Scheithauer, Chorzów, ul. Wieniawskiego 18.

[8] Wyniki badania nr 138/11/N/ - Badania ultradźwiękowe wału maszyny wyciągowej 4L-5500/2×3600 szybu R-II przedział południowy, „Autorytet”, Polkowice, 10.05.2011 r.

[9] Wyniki badania nr 139/11/N/E - Badania nieniszczace wału maszyny wyciągowej 4L-5500/2×3600 szybu R-II przedział południowy, „Autorytet”, Polkowice, 10.05.2011 r.

[10] Pomiary tensometryczne naprężeń w konstrukcji kół pędnych wraz z analizą wyników w maszynach wyciągowych wyciągów górniczych w szybie R-II KGHM Polska Miedź S.A. O/ZG „Rudna”, Katedra Transportu Linowego AGH, Kraków, czerwiec $2010 \mathrm{r}$.

[11] Badania i oceny koła pędnego w maszynach wyciągowych wyciągów górniczych w szybie R-II KGHM Polska Miedź S.A O/ZG „Rudna, Katedra Transportu Linowego AGH, Kraków, październik 2010 r.
[12] Dokumentacja do wniosku o dopuszczenie do stosowania maszyny wyciagowej $4 \mathrm{~L}-5500 / 2 \times 3600$ produkcji firmy $\mathrm{ABB}$ szyb R-II przedziały południowy i północny KGHM Polska Miedź S.A. Oddział ZG „Rudna”, nr dok. 3BPC001189D0144, t. 1 i 2.

dr inż. TOMASZ ROKITA

Katedra Transportu Linowego Wydział Inżynierii Mechanicznej i Robotyki AGH Akademia Górniczo-Hutnicza im. Stanistawa Staszica w Krakowie al. Mickiewicza 30, 30-059 Kraków rokitom@agh.edu.pl 